\title{
The Northern Sea Route cargo transportation development
}

\author{
Aleksey Smirnov ${ }^{1 *}$ \\ ${ }^{1}$ Saint Petersburg State Marine Technical University, 101 Leninskiy pr., Saint Petersburg, 190121, \\ Russia
}

\begin{abstract}
The Northern Sea Route (or the Northern through-passage) is a transport corridor, the use of which is called on in order to increase the efficiency of the Russian economy, activate the natural resources exploration for sub-sovereign entities located in the Arctic zone of Russia. The study purpose is to determine the Northern Sea Route cargo transportation development contemplations in consideration of the observed changes in the world commodity markets. Comparative analysis and a systematic approach is used as the main research methods, which makes it possible to hold a holistic management of ROE of the Northern Sea Route development, implemented at the federal level to ensure a sustainable innovative development of the national economy and the effective use of its resource potentia. The main conclusion is that the volume of cargo transportation along the Northern Sea Route will grow, but at a slower rate than the forecast of the Ministry of Economic Development and will reach 46 to 50 million tons in 2024 .
\end{abstract}

\section{Introduction}

The Northern Sea Route is a new promising transport corridor, stretching from Murmansk to Chukotka, subdividing into the western sector from Murmansk to Dudinka and the eastern sector from Dudinka to Chukotka, which is able to become a highly competitive section of the world's transport system in the future, but only if it is provided with a whole-year shipping traffic in consideration of the need to both fulfill a set of modern requirements for the maritime transportation safety and minimize anthropogenic impact on natural and climatic landscapes of the Russian Federation Arctic regions. Development of the Northern Sea Route was begun as recently as the 17 th century and was carried out gradually, episodically and extremely slowly due to hugely harsh climatic conditions.

A new impetus to the Northern Sea Route mastering was implemented in the 20th century during the active Stalinist industrialization, which made it possible to use this throughpassage on new grounds by the aid of advanced technologies of those times. At the same time, even during the period of the Northern Sea Route active usage in the 1980s, the cargo carriage volume along this through-passage did not pass 7 million tons, which is an insignificant index on the entire economic complex scale. Despite the significant role of the

\footnotetext{
*Corresponding author: al-sm@ rambler.ru
} 
Northern Sea Route in carrying out economic activities in the Russian Federation Arctic regions (in particular, organizing the northern supplies of food, machinery and equipment by the aid of sea and river water routes), only one major investment project was executed within it. What is meant here is the construction of the Norilsk manufacturing district, connected to the Dudinka port by a railway, which is isolated from the rest of the Russian railway system. The consequence of such state of business was a significant slippage of the Northern Sea Route cargo carriage volume in the 1990s, when driven by a decrease in economic activity it fell 2-3 times as compared with the maximum index rates of the previous decade. During the economic downturn the Norilsk industrial cluster ensured the protection of the Northern Sea Route in a capacity of a functioning through-passage in its western part, however, even this project due to its limited cargo carriage volumes could not create the necessary conditions for strong traffic intensity of the NSR for many years to come, that negatively affected its infrastructure, which needs quite significant investments from the government in order to maintain it in working condition. In its eastern part the Northern Sea Route was used only for single cruises at that time.

In fact, a new stage in the Northern Sea Route development began in the 2010s as a result of the disposal of the Yamal LNG project of NOVATEK company, which became the ground for the further development of the through-passage.

Therefore, the problem occurs - how to determine the Northern Sea Route cargo transportation development contemplations, taking into account the pricing environment changes in the world commodity markets, since the world price environment, due to the author's opinion, will largely determine the effectiveness of economic activity in the Arctic zone of Russia. It should be pointed out that the foreign literature mainly addresses the problems of using the Northern Sea Route for the transshipment. Research of this kind begun 10 years ago [1], has been especially active over the past three years [2-5]. As examples of a holistic management of outcome evaluation and development contemplations of the Northern Sea Route, the works of foreign [6-8] and domestic [9,10] authors must be noted.

\section{Material and methods}

Comparative analysis is used as the main research method, which makes it possible to hold a holistic management of ROE of the Northern Sea Route development, implemented at the federal level to ensure a sustainable innovative development of the national economy and the effective use of its resource potential. The article also made use of a systematic approach that provides an integrated management of various factors that have a decisive effect on the Northern Sea Route functioning.

\section{Results}

Since 2011 there has been a significant increase in conveyance of cargo along the Northern Sea Route (table 1)

Table 1. Northern Sea Route cargo carriage volume

\begin{tabular}{|c|c|c|c|c|c|}
\hline Year & $\begin{array}{c}\text { Cargo turnover, } \\
\text { million tons }\end{array}$ & Year & $\begin{array}{c}\text { Cargo turnover, } \\
\text { million tons }\end{array}$ & Year & $\begin{array}{c}\text { Cargo turnover, } \\
\text { million tons }\end{array}$ \\
\hline 1933 & 130 & 1981 & 5005 & 2011 & 3111 \\
\hline 1943 & 289 & 1986 & 6455 & 2015 & 5392 \\
\hline 1953 & 506 & 1991 & 4804 & 2016 & 7265 \\
\hline
\end{tabular}




\begin{tabular}{|l|l|l|l|l|l|}
\hline 1963 & 1264 & 1996 & 1800 & 2017 & 10700 \\
\hline 1971 & 3032 & 2001 & 1860 & 2018 & 19700 \\
\hline 1976 & 4630 & 2006 & 1956 & 2019 & 30000 \\
\hline
\end{tabular}

Since 2013 the implementation of the Yamal LNG project of NOVATEK company has begun, which reached its designed capacity in 2018. It is noteworthy that Yamal LNG with a significant multiplicative effect for the Russian industry and the transport infrastructure development was implemented not by PAO Gazprom, but by a relatively small private company of that time, which managed to provide its project support from the Russian government, without which its implementation would be unprofitable. In our opinion, in the results, economic consequences and the private investment attracted volume the Yamal LNG project has become the most successful example of a public-private partnership in the recent history of Russia, aimed at solving long-term problems of social and economic development and new territories reclamation.

It should be noted that the capital investments in the transport infrastructure development made by the state, including the construction of a new deep water port of Sabetta (the second deepest port on the Northern Sea Route after Murmansk), the construction of icebreakers, and the modernization of the traffic safety providing system successfully supplemented the expenses of the private NOVATEK company, which are directly aimed at the construction of the liquefied natural gas plant itself (the second plant after Sakhalin-2 in Russia) and its production and transportation infrastructure development. This allowed a sharp increase in the Northern Sea Route cargo carriage volume. At the same time, it should be noted that the federal authorities have successfully used the project of a private company to solve the global macroeconomic and geopolitical targets of the Northern Sea Route development by increasing freight traffic.

State investments in the infrastructure development, which have become cost-effective and justifiable precisely due to the Yamal LNG project, have created the necessary conditions for the implementation of other projects for the Arctic zone of Russia development. As a result, according to the geoenergetics.ru website, in 2018 there was an intermittent growth in the Northern Sea Route cargo carriage volume, which in a matter of a year grew sharply by $84 \%$ from 10.7 million tons to 19.7 million tons. For certain cargoes the freight traffic statistics in 2018 are as following: general cargo - 2.34 million tons (-6.3\% year-on-year); coal - 290.8 thousand tons $(-16 \%)$; oil and oil products -7.81 million tons $(+15.6 \%)$; gascondensate - 805.4 thousand tons (7.5 times growth); liquefied natural gas (LNG) - 8.399 million tons (37.7 times growth).

The decrease in general cargo carriage volume occurred due to the completion of the Yamal LNG construction and the reduction in the quantity of work at the Sabetta port. This brand new seaport is designed to provide the necessary infrastructure for the implementation of promising projects at the extractive industries beyond the Polar Circle. Currently, it meets the needs of the Yamal LNG liquefied natural gas plant. The intermittent growth in LNG transportation volume is a consequence of the completion of this NOVATEK company project and putting the second and third technological stages into service.

According to the author, in the next four years the volume of cargo transportation along the Northern Sea Route will grow, but will not reach 80 million tons. (Table 2).

Table 2. Northern Sea Route cargo carriage forecast 


\begin{tabular}{|c|c|c|c|}
\hline Year & $\begin{array}{c}\text { Cargo turnover, million } \\
\text { tons }\end{array}$ & Year & $\begin{array}{c}\text { Cargo turnover, } \\
\text { million tons }\end{array}$ \\
\hline 2021 & $31-33$ & 2023 & $35-40$ \\
\hline 2022 & $33-35$ & 2024 & $46-50$ \\
\hline
\end{tabular}

\section{Discussion}

The importance of the Northern Sea Route development project for the industry development in the Russian Federation exists due to the fact that there is still a not overcome gap in most sectors between the national economy and advanced economies, which affects the rate of economic growth negatively, and does not allow to fully utilize the national economy competitive opportunities. A negative factor affecting the national economy growth rate is the sanctions imposed by industrialized countries. The impact of the sanctions, as well as the consequences of the rupture of military-technical working relationship with Ukraine (which had been successfully and effectively carried out since Soviet times) are quite significant in the shipbuilding products manufacture, which are also used on the Northern Sea Route.

Hence it is getting all the more important to develop the technological areas in which the industry of the Russian Federation maintains advanced positions in the world. In the first instance, we are referring to the atomic icebreakers construction, absence of which will make a year-round navigation on the Northern Sea Route impossible. Russia is the only country in the world capable of such watercrafts production due to the unique nature of the domestic shipbuilding enterprises existing competencies (first of all, OJSC Baltic Shipyard). Thus, the atomic icebreaker is an innovative research-intensive product of domestic shipbuilding, which has no analogues in the world and is necessary for the projects implementation in the Arctic zone of Russia.

At the same time, icebreakers of the latest serial project LK-60Ya not only have a powerful power electric plant that makes them able to ram ice up to $3 \mathrm{~m}$ thick, but they can also be used in shallow waters at the mouths of the rivers because of the special design of the hull. The existence of a nuclear power plant dramatically increases the autonomy of such vessels, which is especially important and highly required within the conditions of the Arctic zone of Russia, which is characterized by large distances between settlements.

At the same time, such modern innovative vessels have a high cost. Thus, the cost of the last and most expensive vessel of the LK-60YA project (it does not have a name yet) excels 50 billion rubles, which is more than 700 million euros at the current currency rate. Therefore, the production of such vessels can be justified only if they are much-in-demand for solving important economic tasks of a long-range promising nature. Consequently, the usage of such vessels can be economically viable unless and until the large cargo carriage volumes are kept, which will at least compensate for current exploitation costs, and in the long term break even the entire project of the nuclear icebreakers construction. Therefore, it is absolutely logical that it is needed to increase the Northern Sea Route cargo carriage volumes up to at least 80 million tons in order to develop the pioneering branches of industrial production, which is defined by the Decree of the President of Russia V.V. Putin No. 204 of May 72018 «On national goals and strategic issues of the Russian Federation development for the period until 2024" as a target point by the year 2024 [11].

In our opinion, a certain contradiction arises under these circumstances. On the one hand, in order to recoup the icebreaker fleet it is necessary to ensure a significant increase in cargo transportation from 10.7 million tons in 2017 to 80 million tons in 2024, i.e. almost by 8 times in 7 years. On the other hand, for such an increase in cargo carriage volume it is required to provide tax advantages and other preferences for private companies, which are 
implementing investment projects in the Arctic zone of Russia. In this situation the government of the Russian Federation becomes kind of a hostage of private business, for only with its active participation the government can achieve the targets set by the President of our country. There emerge the risks that the business will push the government for obtaining unreasonable preferences in exchange for an increase in the Northern Sea Route cargo carriage volumes, which will negatively affect the effectiveness of management decisions.

\section{Conclusions}

These days the growth in the liquefied natural gas transportation is the main factor which should ensure a further increase in the Northern Sea Route cargo carriage volumes. It is associated with the low pace of other promising projects implementation focused on the Arctic raw material resources base development, economic difficulties arising in the process of their implementation during a detailed economic effect calculation, taking into account the alterations in the pricing environment. Thus, Vostokugol company coal mining projects in Taimyr are temporarily suspended. In our opinion, the main reason for that is a sharp decline in world coal prices, which makes the implementation of such large-scale projects unprofitable under the rough conditions of the Far North.

The possibility of other raw material resources projects implementation in the Northern Sea Route area will also depend significantly on the pricing environment on the world market. During the period of a sharp increase in international markets prices, the cost effectiveness of such projects grows, which allows us to consider the Arctic zone of Russia as a country's promising raw material resources base in the short term. However, prices on the world market are subject to wide swings, which are often quite difficult to predict even using a modern instrument of scientific prognosis. It is enough to cite an instance of the Shtokman gas and condensate field, the development of which was actively planned under the conditions of high prices for natural gas, and was postponed indefinitely driven by a negative change in the world pricing environment. And this despite the fact that the investment, lobbist and analytical potential of Gazprom, which at one time was planning the development of the Shtokoman field, are far cry from the potential of smaller Russian companies. In this regard, the implementation of investment intensive projects in the Arctic zone of the Russian Federation with a long payback period requires the implementation of a set of government support measures that guarantee investors the necessary amount of return on the contributed capital.

Such an approach will be justified only if measures of State support for the raw material resources projects in the Arctic zone require less financial resources from treasuries at all levels than the complex social-and-economic effect yielded after their implementation. However, due to the specific nature of price settings on the world market, that have been already noted, the performance evaluation seems difficult, which leads to a decrease in the investment attractiveness of the Arctic zone of the Russian Federation under the current conditions.

In addition, taking into account the extraordinary environment of the Arctic, it seems that the implementation of the raw material resources extraction projects in the Arctic zone should be carried out by large companies that already have positive experience in minimizing the anthropogenic impact in the raw material resources industries, which will allow to significantly reduce ecological risks, decrease negative environmental impacts and will positively affect the level of the cumulative social-and-economic effect. At the same time, the implementation of raw material resources projects in the administrative-territorial entities located beyond the Polar Circle requires control by the federal executive authorities with the involvement of environmental public organizations, that have in practice proved their ability 
to meaningfully interact with business and government and have considerable authority with society.

In addition to natural gas from the Yamal LNG and Arctic LNG-2 projects, whole oil from the Vankor cluster of "Rosneft Oil Company" projects (Suzunskoye, Tagulskoye and Lodochnoye fields) should become an essential component of the freight flow along the Northern Sea Route in 2024. It appears that unlike projects in the coal mining field, the oil industry projects have a much higher probability of successful implementation, which contributes to a number of factors, the most important of which are high oil prices.

The through haulage capabilities of the Northern Sea Route should be assessed with caution. The following is necessary for through haulage growth: the ice situation improvement in the route zone (which will be possible only in the case of further climate warming, allowing to use it year-round), increase in the cargo carriage volume by domestic companies in the eastern direction (foreign companies will only come to the route that has already been mastered by national freight carriers), a modification of the maritime transportation safety system, an increase in geopolitical tension on other freight routes. At the same time, the very development of the Northern Sea Route excludes the possibility of increasing of US political pressure on China through the threat of its trade routes blockade (closing of the Suez Canal or the Strait of Malacca) and thereby serves as one of the tools to ensure the world economic resilience.

\section{References}

1. J. Verny, C. Grigentin, Journal of Production Economics, 122(1), 107-117 (2009). doi.org/10.1016/j.ijpe.2009.03.018

2. Y. Zhang, Q. Meng, S. HuiNg, Journal of Transport Geography, 57, 241-249, (2016). doi.org/10.1016/j.jtrangeo.2016.09.008

3. A.-S. Milaković, B.Gunnarsson, S. Balmasov, S. Hong, K. Kim, P. Schütz, S. Ehlerse, Marine Policy, 94, 53-60 (2018). doi.org/10.1016/j.marpol.2018.04.027

4. D-Y. Lin, Y-T. Chang, Transportation Research Part E: Logistics and Transportation Review, 110, 47-70 (2018). doi.org/10.1016/j.tre.2017.12.003

5. H. Wang, Y. Zhang, Q. Menga, Transportation Research Part A: Policy and Practice, 107, 75-89 (2018). doi.org/10.1016/j.tra.2017.11.010

6. M. Keupp, The Northern Sea Route: A Comprehensive Analysis. (Berlin, Springer Gabler. 2015) doi: 10.1007/978-3-658-04081-9.

7. T. Pastusiak, Voyages on the Northern Sea Route (Berlin: Springer Gabler, 2016). doi: 10.1007/978-3-030-25490-2

8. N. Otsuka, K. Izumiyama, M. Furuichi, Proceedings of the 22nd International Conference on Port and Ocean Engineering under Arctic Conditions, 22, 225 (Finland, Espoo, 2013). Retrieved from http://www.poac.com/PapersOnline.html.

9. E.S. Palkina, IOP Conference Series: Earth and Environmental Science. 90 (1) (2017) doi: 10.1088/1755-1315/90/1/012070

10. A. Abramov, M. Zagorodnikov, A. Smirnov, Modern Tools for Sustainable Development of Territories. Special Topic: Project Management in the Regions of Russia (MTSDT, 2019). doi 10.15405/epsbs.2019.12.05.125

11. A. Smirnov, Proceedings of the International Conference on Digital Technologies in Logistics and Infrastructure (ICDTLI, 2019). doi 10.2991/icdtli-19.2019.8 